\title{
Komunikasi Interpersonal Antar Orang Tua Dan Anak Terhadap Karakter Anak
}

\author{
Haliza Lufipah ${ }^{1}$, Bayu Pamungkas ${ }^{2}$, Mulki Pasha Haikal ${ }^{3}$,Trismalia Putri Siregar ${ }^{4}$, Prudensia \\ Ira Pingga ${ }^{5}$ \\ 1,2,3,4,5Program Studi S1 IImu Komunikasi, Fakultas IImu Komunikasi, Universitas Islam Nusantara
}

$\begin{array}{r}\hline \text { A R T I C L E I N F O } \\ \hline \text { Article history: } \\ \text { Received Sep 03, } 2021 \\ \text { Revised Sep 22, } 2021 \\ \text { Accepted Des 30, } 2021 \\ \hline\end{array}$

Keywords:

Interpersonal Communicatin; Effectif Communication;

Parent;

Children.

\begin{abstract}
Research on this problem aims to understand the interpersonal communication of parents on the character of their children to build an effective communicative attitude, and to develop children's communication skills in the family environment and in the community, so that parental communication can be open and easy to understand. The research method used is a qualitative approach with descriptive analysis of qualitative data. The data used is through in-depth interviews with two informants, namely the father and mother. The results of research conducted from the results of theories associated with the results of interviews that obtain and explain that some parents want their children to be more open and consider their children as friends to improve the quality of two-way interpersonal communication in children towards the character of the child so that interpersonal communication is always always done by parents, the child's character becomes more confident and always open.
\end{abstract}

\begin{tabular}{|c|}
\hline \\
\hline $\begin{array}{l}\text { Penelitian pada pemasalahan ini bertujuan untuk memahami } \\
\text { komunikasi interpersonal orang tua terhadap karakter anak untuk } \\
\text { membangun sikap komunikatif yang efektif, dan mengasas } \\
\text { kemampuan komunikasi anak di lingkungan keluarga maupun di } \\
\text { lingkungan masyarakat, supaya komunikasi dengan orang tua dapat } \\
\text { saling terbuka dan mudah dipahami. Metode penelitian ini yang } \\
\text { digunakan ialah pendekatan kualitatif dengan anasis deskriptif data } \\
\text { kualitatif. Data yang digunakan melalui wawancara mendalam dengan } \\
\text { dua informan yaitu ayah dan ibu. Hasil penelitian yang dilakukan dari } \\
\text { hasil teori - teori yang dikaitkan dengan hasil wawancara yang } \\
\text { memperoleh dan menjelaskan bahwa sebagian orang tua } \\
\text { menginnginkan anak lebih terbuka dan menggangap anak sebagai } \\
\text { teman untuk meningkatkan kualitas komunikasi interpersonal yang dua } \\
\text { arah pada anak terhadap karakter yang dimiliki anak sehingga } \\
\text { komunikasi interpersonal selalu senantisa dilakukan oleh orang tua } \\
\text { karakter anak menjadi lebih percaya diri dan selalu terbuka. }\end{array}$ \\
\hline
\end{tabular}

This is an open access article under the CC BY-NC license.

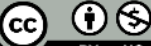

\section{Corresponding Author:}

Haliza Lufipah

Program Studi S1 IImu Komunikasi, Fakultas IImu Komunikasi,

Universitas Islam Nusantara,

Jl. Soekarno-Hatta No.530, Sekejati, Kota Bandung, Jawa Barat 40286

e-mail : hlufifah@gmail.com

\section{PENDAHULUAN}

Komunikasi merupakan bagian yang terpenting pada kehidupan manusia, dikarenakan oleh hal lain manusia merupakan makhluk sosial, untuk saling berinteraksi dengan manusia lainnya, baik komunikasi interpersonal maupun kelompok. Salah satu komunikasi yang ada di lingkungan 
terdekat yaitu keluarga. Keluarga ialah bagian yang terkecil dalam masyarakat, proses komunikasi sebuah keluarga seperti kepala keluarga dan anggota keluarga lainnya. (Yusuf Indrawan, dkk 2019). Namun, menurut (Sri lestari, 2018), bahwa ada tiga jenis dalam keluarga yaitu keluarga inti (nuclear family), keluarga poligami (family polygamy), dan keluarga besar (extended family).

Komunikasi interpersonal dengan orang tua dan anak, mampu memelihara suatu hubungan yang utuh. Bayangkan jika masing-masing anggota jarang berbicara dan tidak mau mendengarkan atau menanggapi ketika anggota keluarga lain mengajaknya berbicara atau hanya diam dan mengikuti perintah orang tuanya karena takut mulai berbicara. Tentu saja, keluarga tidak memiliki hubungan dekat. Komunikasi interpersonal merupakan komunikasi yang sangat efektif dalam mempengaruhi seseorang, karena bersifat dua arah dan panca indera digunakan sebagai alat yang dapat memberikan pengaruh besar terhadap perubahan sikap, apabila terlau masing masing maka mereka akan seperti orang asing yang berkumpul dalam satu atap. (Muslimin dkk, 2018)

Menurut (Deddy Mulyana 2018) Ada istilah We cannot not communication, yang artinya kita tidak bisa tidak berkomunikasi, karena semua perilaku adalah komunikasi. Terutama dalam hubungan komunikasi orang tua dan anak, tujuannya untuk dibina dan dibimbing dengan baik. Dalam konteks ini, anak harus berkomunikasi dengan siapa saja di masyarakat atau keluarga untuk menjaga keeratannya, terutama dengan orang tuanya, anak harus mengerti dan menuruti perintah orang tua, begitu pula sebaliknya orang tua harus mendidik anaknya dengan baik. Orang tua merupakan tempat bagi anak-anak untuk saling berbagi komunikasi. (Rakhmawati,2015)

Menurut, (Tri Endang Jatmikowati, 2018). Bahwa hubungan komunikasi pada keluarga dibangun secara efektif oleh orang tua untuk anak dengan kapasitas dan keberanian anak untuk mengambil keputusan. Intensnya hubungan komunikasi orang tua dan anak sangat membantu keefektifitas suatu hubungan psikologis sehingga pendekatan parenting yang bersifat sepihak..

Menurut (Fitria indriani, 2020), dapat dikatakan bahwa interaksi orang tua dan anak dengan melakukan suatu komunikasi sangat berpengaruh terhadap kelancaran komunikasi untuk membentuk suatu karakter anak, semua orang tua menginginkan anaknya memiliki karaktek yang lebih baik. Orang tua harus menerapkan komunikasi mengajak anak untuk memulai berbicara.

Peran aktif orang tua sangat bermanfaat bagi proses hubungan emosional anak, yang dapat dilihat sebagai bentuk dukungan terkait pembentukan tumbuh kembang anak, untuk melepaskan daya kreatif dan imajinasi anak yang berdampak positif dan tentunya anak selalu fokus dalam membangun karakternya. (Kurniawan dkk, 2020)

Karakter pada anak dapat dibentuk dari pasangan kedua orang tua dengan karakter. Dimulai dengan ibu dan ayah yang sudah menikah, mereka siap menjadi ayah di masa depan yang memiliki anak yang dibesarkan sesuai dengan akar budaya ayah dan ibu mereka untuk menjalin komunikasi yang dua arah yang menerapkan sikap menyimak karena menyimak berarti memperhatikan, memahami, mengevaluasi suatu rangsangan yang akan diterima. Artinya mendidik anak berkaitan dengan komunikasi, sangat penting untuk mendengarkan dan memahami perasaan apa yang dirasakan pada anak. (Meni Handayani, 2016)

Keterlibatan dan ajaran orang tua terhadap anaknya memiliki pengaruh yang sangat kuat membentuk karakter kepribadian dan juga untuk membentuk rasa percaya diri pada anak. Orang tua merupakan perantara kehadiran anak-anaknya di muka bumi, yang pertama mengasuh, mengajar dan mendidik. Jika anak terlibat dalam kegiatan yang tidak baik, orang tua segera menghentikannya, memberikan pemahaman tentang bahaya yang dapat membahayakan anak. Dengan cara ini, anak akan lebih memahami pengalaman yang berasal dari orang tuanya sendiri. Perkembangan dan karakter anak pada pembentukan kepribadian tumbuh dan berkembang, ada beberapa cara untuk membangun karakter anak antara lain membangun kejujuran; ketulusan; kepedulian terhadap orang lain; agar penanaman dan pertumbuhan karakter anak ditumbuhkan sejak usia dini. (Kholifah dkk, 2019).

Dengan demikian, untuk menghadapi karakter anak, orang tua harus melakukan serangkaian dialog yang baik dengan anak-anaknya. Interaksi atau komunikasi yang baik, hangat dan penuh keakraban sehingga selalu ada timbul keinginan yang membuat anak tidak memberikan kesulitan pada diri anak. Dalam hal ini, proses relasi antara orang tua dan anak untuk mendukung 
perkembangan fisik, emosional, sosial, intelektual dan spiritual berlangsung sejak anak dalam kandungan hingga dewasa. (Lubis, dkk 2019)

Hal inilah yang membuat peneliti tertarik untuk meneliti bagaimana agar anak dapat membangun karakter komunikasi, membangun karakter percaya diri, membangun karakter harga diri yang positif dan membantu orang tua memahami perkembangan setiap anak dalam hubungan komunikasi yang berkualitas yang diberikan orang tua kepada anak. menentukan karakter kualitas kepribadian dan akhlak. Karakter anak yang diasuh oleh orang tuanya dapat dikembangkan sejak dini untuk penanaman dan penumbuhan karakter anak yang paling efektif, proses komunikasi dan teladan dari orang tua pada anak.

\section{METODE PENELITIAN}

Metode yang digunakan metode pendekatan kualitatif, pendekatan kualitatif ialah penelitian yang menggunakan data - data yang cukup untuk dapat diteliti dengan baik berdasarkan latar ilmiah. Dari data - data yang telah di dapatkan, maka penelitian kualitatif akan dapat di analisis dan dilihat dilapangan sehingga hasil dari penelitian akan lebih akurat. Pengumpulan data penelitian ini menggunakan deskriptif kualitatif sebanyak data yang sama bertujuan untuk meneliti, menganalis, menggambar, dan meringkas dan menjelaskan berbagai sumber aspek individu tentang permasalahan yang telah diteliti berdasarkan berbagai kondisi dari situasi dari berbagai data yang dikumpulkan berupa hasil wawancara/pengamatan mengenai masalah yang diteliti di lapangan mendalam terhadap informan. (Sugiyono,2018).

Penelitian ini dilakukan di Komplek. Griya Bandung Indah, Desa Buahbatu, Kecamatan Bojongsoang, Kabupaten Bandung, Waktu yang digunakan untuk penelitian ini ialah bulan Juni 2021. Subjek pada penelitian ini ialah kedua orang tua, pada hal ini di fokus untuk meneliti di beberapa rumah saja, dikarenakan kasus hanya terjadi pada hubungan komunikasi pada orang tua tersebut saja.

Informan pada penelitian ini merupakan orang yang akan dimanfaatkan untuk memberikan informasi situasi dan kondisi yang berkaitan dengan latar belakang yang benar-benar mengetahui permasalahan yang akan diteliti. Informan pada penelitian ini sebanyak dua orang ayah dan ibu yang merupakan latar belakang masalah pada penelitian yang telah mendidik anaknya agar terbentuk komunikasi terhadap karaktek anak.

Teknik analisis data menggunakan teori induksi, yaitu dimana peneliti harus memfokuskan perhatiannya didalam data yang ada di lapangan sehingga data yang akan dikumpulkan lebih akurat yang akan dibangun teori berdasarkan temuan data pada lapangan. Data hasil dari penelitian yang dapat memecahkan semua kasus pada penelitian, dan apabila peneliti secara kebetulan telah memiliki pemahaman tentang teoritis tentang data yang akan diteliti, maka proses pembuatan teori itu wajib dilakukan penyederhanaan data kedalam bentuk yang lebih mudah dibaca. Setelah memperoleh data dari berbagai sumber yang dikumpulkan sesuai urutannya, kemudian diorganisasikan kedalam satu pola, kategori dan uraian dasar, kemudia data dianalisis secara kualitatif yang diuraikan secara deskritif.

\section{HASIL PENELITIAN DAN PEMBAHASAN}

Bentuk Keefektifan hubungan komunikasi interpesonal orang tua dan anak, Bentuk keefektifan komunikasi interpersonal terhadap anak merupakan bagaimana cara orang tua berkomunikasi pada anak, mendidik dan menanamkan sikap serta perilaku yang baik pada anak, percakapan yang dua arah ini menunjukkan terjadinya suatu interaksi komunikan dan komunikator. Percakapan yang selalu dilakukan dengan orang tua kepada anak secara langsung yang seringkali diucapkan akan ada timbal baik dimana anak akan menirukan percakapan orang tua tersebut. Orang tua seharusnya mendidik dan mengajarkan, dan menanamkan nilai sikap dan perilaku yang baik pada anak dalam menyikapi kehidupan dalam pergaulan anak di lingkungan luar.

Menurut hasil penelitian yang dilakukan melalui wawancara, jawaban yang tepat dapat diperoleh kemudian dijabarkan dan dijelaskan menurut informan bagaimana pola asuh orang tua dan anak terhadap karaktek anak untuk mecinptakan komunikasi interpesonal. Hasil wawancara ini dapat dijelaskan melalui jawaban dan pertanyaan-pertanyaan yang diajukan pada berikut ini : 
Informan 1, menjelaskan bahwa mengajarkan keefektifan komunikasi orang tua terhadap anak adanya keterbukaan dan saling berempati.

Informan 2, menjelaskan Orang tua itu harus selalu sering mengajak ngobrol anak, dan orang tua menjadikan anak sebagai teman agar anak lebih terbuka dan cenderung tidak canggung.

Informan 3, menjelaskan bahwa keterbukaan akan membuat lebih anak mudah bercerita tentang masalah yang dialaminya.

Informan 4, menjelaskan hubungan komunikasi yang baik adalah mendengarkan cerita dan memberikan solusi terhadap anak.

Informan 5, menjelaskan walaupun orang tua sibuk bekerja, kewajiban kita sebagai orang tua itu harus memperhatikan anak agar bisa memantau perkembangan anak dalam pembentukan karaktek anak.

Menurut, (Rio Ramdhani, 2013) mengemukakan bentuk komunikasi interpesonal orang tua dan anak untuk memberikan pesan dan informasi yang dapat mengubah sikap anak untuk membentuk perilaku positif. Ini menunjukan bahwa sangat kerap untuk menjadi komunikator dengan banyak hal.

Namun, menurut kami hubungan komunikasi orang tua bisa saja berbeda-beda dikarenakan apabila orang tua terlalu fokus pada perkejaannya dan seringkali pulang sampai larut malam itu takkan bisa menjadi komunikasi yang efektif, karena tidak adanya terjalin komunikasi yang dua arah, apabila orang tua ada komunikasi mungkin paling tidak banyak untuk berbicara. Sedangkan, bahwa komunikasi interpersonal tidak akan berjalan efektif untuk membentuk perilaku yang positif, apabila orang tua dan anak tidak saling egois dan akan menegur satu sama yang lain. Apabila orang tua memang orang tua sibuk dalam bekerja setidaknya orang tua bisa meluangkan waktunya sebentar untuk anaknya, saling mendengarkan keluh - kesah. Orang tua yang menjadikan pendengar yang baik merupakan yang akan terjadinya komunikasi yang lebih efektif karena orang tua mampu mengamati dan memperhatikan sikap dan perilaku anak.

Bagaimana pola asuh komunikasi kedua orang tua untuk membangun karaktek anak, Sebagai dasar perilaku pola komunikasi kedua orang tua untuk membangun karaktek anak dalam berkomunikasi merupakan relasi komunikasi dua arah antara orang tua dan anak yang harus dilakukan dengan baik dan terarah sehingga mendapatkan hasil yang diharapkan. Terkadang relasi komunikasi dua arah tidak sesuai dengan yang diharapkan dikarenakan banyak faktor dan hambatan dalam membangun pola asuh untuk membangun karakter anak. Hambatannya itu kadang anak susah untuk dibilangin bahwa apa yang anak lakukan itu salah tetapi anak selalu membantah apa yang orang tua ajarkan. Contohnya : ketika anak sudah menggunakan Handphone ( $\mathrm{Hp}$ ) yang tidak tau waktu orang tua akan marah karena sama sekali tidak melakukan aktivitasnya tetapi anak malah mengabaikan percakapan orang tua tersebut.

Menurut hasil wawancara dengan kedua orang tua menjelaskan bahwa :

Informan 1, menjelaskan, bahwa membangun karaktek anak harus mengganggap anak sebagai teman.

Informan 2, menjelaskan bahwa membangun karaktek komunikasi dengan anak dengan kondisi baik serta nyaman, dan hindari memojokon anak jika dia salah tapi berilah nasehat yang baik anak merasa bahwa dia tak menjadi orang yang paling terpuruk apabila mendapatkan masalah, maka anak tidak akan takut bercerita kepada orang tua.

Informan 3, menjelaskan bahwa membangun karaktek anak yang baik orang tau harus menggangap anak sebagai teman, tidak canggung dan tidak menutupi diri.

Informan 4, menjelaskan komunikasi harus dimulai dari hubungan yang erat dengan orang tua dan anak, karena dengan begitu akan menjalin suatu komunikasi yang baik dan efektif.

Informan 5, menjelaskan bahwa komunikasi yang baik adanya keterbukaan antara orang tua dan anak

Menurut, (Desy Indriani, 2018) mengemukakan bahwa hubungan komunikasi yang baik dengan orang tua menjadikan kita menjadi perilaku yang lebih baik dalam berfikir positif tentang dirinya sendiri yang akan mencintai dirinya sendiri. 
Menurut, kami pola asuh orang tua dalam berkomunikasi yang baik akan terbentuknya suatu karaktek anak yang diterapkan oleh masing-masing orang tua yang terdiri ayah dan ibu. Suatu karakter yang pasif akan membuat komunikasi dengan anak tidak berjalan efektif dikarekan kurangnya interaksi terhadap anak sehingga, munculnya suatu komunikasi yang canggung dan anak menjadi takut berkomunikasi dengan orang tua. Maka orang tua harus menjadi sahabat agar anak nanti lebih cenderung lebih terbuka untuk mengungkapkan apa yang ingin dia ungkapkan (Tidak canggung). Setiap masalah atau kecangungan tidak akan hilang begitu saja jika anak menghidari suatu komunikasi dengan anak. Maka dari itu selalu lakukan komunikasi keterbukaan antara orang tua dan anak akan tercipta karakter kepribadian anak-anaknya. Apabila sebagai orang tua sudah mendengarkan cerita anak-anaknya maka akan terjalin komunikasi yang baik selalu memiliki dua jalur dalam menyampaian pesan dan jalur dalam pendengar pesan.

Pola asuh komunikasi yang baik pada anak yang akan membentuk setiap karaktek anak yaitu, saling terbuka dan berbagi cerita, jangan saling memojokan anak apabila anak berbuat salah, tetapi beri nasehat dengan cara yang baik yang akan anak tidak segan untuk memulai bercerita dan memberi tahu apa yang anak perbuat itu tidak baik. Orang tua harus lebih aware dalam mengamati setiap sikap dan perilaku anak supaya anak akan menjadi perilaku yang lebih baik dan lebih berfikir positif.

Bagaimana peran komunikasi kedua orang tua dalam mendidik anak, Peran komunikasi orang tua terhadap anak merupakan suatu tindakan yang harus memastikan bahwa anak tidak kenapa ada masalah yang ditutupi sehingga membuat anak menjadi menutup diri dari. Orang tua seharusnya menjadi kuantitas pada anak untuk mengetahui sikap dan perilaku anak yang akan terjadi pada diri anak.

Menurut hasil wawancara yang dijelaskan oleh orang tua yaitu ayah dan ibu yaitu :

Informan 1, menjelaskan bahwa sesibuk apapun orang tua dalam melakukan pekerjaan, kita sebagai orang tua harus mempunyai waktu luang untuk anak.

Informan 2, menjelaskan bahwa kesibukan ornag tua dalam hal mendidik anak tidak boleh diabaikan begitu saja harus memiliki rasa tanggung jawab bukan hanya berupa uang tetapi rasa kasih sayang terhadap anak merupakan salah satu dari terbentuk karaktek anak dalam berkomunikasi.

Informan 3, menjelaskan bahwa bagaimana situasi mereka tetap harus tetap berusaha membuat anak nyaman ketika berkomunikasi dengan orangtuanya.

Informan 4, menjelaskan orang tua mengarahkan anak sehingga menemukan jati dirinyanya sesusai keinginan, serta memantau segala kegiatan atau aktifitas anak sehingga anak dapat membedakan hal positif dan juga negatif.

Informan 5, menjelaskan bahwa salah satu membentuk karaktek anak dalam berkomunikasi ialah bercerita.

Menurut (Aldenis Mohibu, 2015), Mengemukakan bahwa, hubungan komunikasi antara orang tua dan anak, sangat membantu keefektifan hubungan psikologis anak terhadap pendekatan orang tua menjadi dua arah untuk mengetahui perkembangan anak dalam usia remaja dalam pertumbuhan yang mengarah pada proses pembentukan aktualisasi diri yang lebih baik agar anak dapat terbentuk karaktek yang saling terbuka satu sama yang lain.

Namun, menurut pemahanan kami bahwa peran kedua orang tua yang harus dilakukan ialah mendukung apa yang anak inginkan untuk mengejar masa depannya, jangan terlalu memaksa bahwa anak harus menuruti semua yang orang tua inginkan. Orang tua harus menerima dan menjalankan suatu peran yang berkualitas dalam mendidik anak. Orang tua perlu menyadari bahwa psikologis anak lebih penting bahwa hal yang menyenangkan anak yaitu mendukung. Orang tua harus selalu meluangkan waktu itu anak agar anak tidak merasa kesepian karena kebahagian anak bukan hanya berupa uang tetapi anak menginginkan suatu kebahagian yang orang tua berikan.

Peran orang tua dalam mendidik anak untuk membentuk karaktek anak dalam berkomunikasi yaitu meluangkan waktu, mendukung keinginan anak bahwa anak aset orang tua yang harus di jaga sampai Tuhan mengambilnya. Peran dalam komunikasi antara orang tua dan anak biasanya pada saat berkumpul di rumah dan lakukan komunikasi Family time yang akan terciptanya suatu hubungan komunikasi untuk mengetahui seperti apa anak - anak ketika sedang berada di lingkungan masyarakat. Anak akan mulai bercerita tentang pengalaman yang terjadi 
pada dirinya yang lakukan di luar rumah, maka anak berharap orang tua mendengarkan apa yang mereka harapkan yaitu, salah satunya dengan cara memahami dari cerita mereka, berempati mendengarkan keluh-kesahnya, sesungguhnya anak bukan hanya menganggap orang tua sebagai orang tuanya yang tentu tidak saja hanya memenuhi kebutuhan anak melainkan anak membutuhkan figur orang tua menjadikan seorang sahabat ketika berada di lingkungan rumah. Orang tua yang baik harus mampu menjadi sahabat yang bagi anak-anaknya untuk menjadi tempat berbagi beban hidup dan untuk merencanakan masa depan yang baik untuk anakanaknya. Karena dapat kita ketahui bahwa hubungan komunikasi banyak kegagalan dalam berkomunikasi yang efektif untuk saling melengkapi karena banyak kegagalan ddan kesalahpahaman dalam memahami isi pesan yang kita pahami tidak terjalin dengan baik.

Hubungan komunikasi verbal orang tua dan anak, Menurut hasil wawancara dari komunikasi verbal orang tua terhadap anak yaitu :

Tabel 1. hasil wawancara dari komunikasi verbal orang tua terhadap anak

\begin{tabular}{|c|c|c|}
\hline No & Informan & Komunikasi verbal \\
\hline 1 & Informan 1 & $\begin{array}{l}\text { - Menggunakan bahasa Indonesia } \\
\text { - Menggunakan kata - kata baik yang mudah dipahami }\end{array}$ \\
\hline 2 & Informan 2 & $\begin{array}{l}\text { - Menggunakan bahasa Indonesia } \\
\text { - Berbicara yang sopan dan lembut }\end{array}$ \\
\hline 3 & Informan 3 & $\begin{array}{l}\text { - Menggunakan bahasa Indonesia } \\
\text { - Berbicara dengan nada pelan } \\
\text { - Tegas } \\
\text { - Tidak berbicara kasar }\end{array}$ \\
\hline 4 & Informan 4 & $\begin{array}{l}\text { - Menggunakan bahasa Indonesia } \\
\text { - Tidak berbicara kasar }\end{array}$ \\
\hline 5 & Informan 5 & $\begin{array}{l}\text { - Menggunakan bahasa Indonesia } \\
\text { - Berbicara baik }\end{array}$ \\
\hline
\end{tabular}

Menurut (Agus Irianto,dkk 2018). Mengemukakan bahwa komunikasi orang tua - anak merupakan fungsi perkembangan dan bahwa semua aspek membuka kepribadian anak pada perilaku positif, empati dan perilaku suportif, karena komunikasi orang tua dan anak merupakan sesuatu yang dapat digunakan untuk menanamkan nilai-nilai sikap keterampilan dan bahasa yang baik untuk membentuk kepribadian anak yang lebih baik.

Menurut kami bahwa komunikasi yang baik dimulai dari orang tua tidak berbicara kasar karena apabila orang tua berkata kasar terus menerus akan menciptakan dampak buruk terhadap anak dan anak akan lebih arogan apabila anak sedang berada di luar rumah untuk meluapkan kekesalan yang ada di dalam rumah. Orang tua harus memulai komunikasi yang mengajak anak mulai anak berbicara yaitu berbicara baik dan lembut namun tegas.

Komunikasi akan berjalan dengan baik apabila orang tua bisa memahami dulu sikap dan perilaku anak dalam berkata. Orang tua akan terus dijadikan pendoman dan contoh untuk mengembangkan suatu karaktek agar anak menjadi kepribadian yang selalu baik, karena jika orang tua gagal dalam mendidik anak - anaknya akan terpengaruh lingkungan masyarakat, dengan demikian anak akan menjadi kepribadian yang tidak baik dalam bergaul dan adanya pemberotakan yang merugikan dirinya. Langkah yang harus orang tua lakukan untuk menghindari agar anak - anak tidak terjerat di lingkungan di luar adalah lakukan diskusi, berikan informasi dan penjelasan tentang dirinya apa saja yang tidak boleh dilakukan tentang dirinya apabila sedang berada di luar rumah dan selalu terapkan sikap bertanggung jawab dalam apa yang anak - anak yang telah di perbuatnya. Dengan begitu anak - anak akan selalu tanamkan dibenaknya hingga ia dewasa nanti berdasarkan fitrahny.

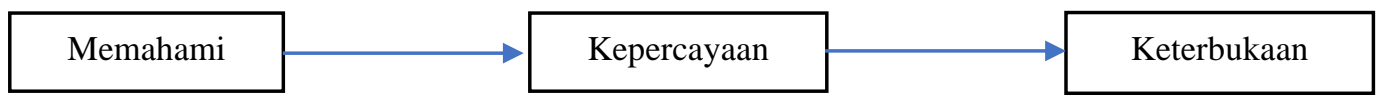

Gambar 1. Proses komunikasi interpesonal orang tua dan anak

Hubungan komunikasi interpersonal orang tua dan anak terhadap karakter anak secara tidak langsung menimbulkan keterbukaan dalam berkomunikasi, tetapi pada saat melakukan 
komunikasi dua arah terdapat beberapa tahap, pada tahap ini bisa dikatakan bahwa komunikasi yang telah dilakukan oleh informan hanya sampai keterbukaan, keduanya masih harus saling melakukan interaksi dan memahami, proses komunikasi keterbukaan yang terjadi antar orang tua dan anak harus melakukan sebagian besar sesuai dengan hubungan interpersonal. Hubungan tersebut diawali dengan penyampaian pesan, dimana penyampain pesan tersebut antar keduanya terjadi pada saat proses ketika melakukan Family time pada saat mereka berkumpul di dalam rumah yang dimaksud saling berinteraksi, yang kemudian pada tahap selanjutnya kepercayaan, dimana orang tua harus saling berkomunikasi yang terjalin dengan anaknya, maka anak tidak akan menyembunyikan apapun terhadap orang tuanya, dengan demikian orang tua pun harus memberikan kepercayaan kepada anak. Tahap selanjutnya yaitu memahami segala tingkah laku anak yang terjadi pada perkembangan karaktek anak.

\section{KESIMPULAN}

Pada dasarnya komunikasi interpesonal untuk membentuk karakter anak, masih terdapat bahwa perilaku yang positif ialah keterbukaan komunikasi orang tua dan anak yang cukup baik walaupun tidak semua pesan dapat mengubah karakter anak dalam tidakan dihadapan orang tuanya, karena memang itu semua butuh waktu yang harus di tanamkan dari nasehat dari orang tuanya, terkadang secara tidak langsung perilaku yang positif dapat berjalan dengan dua arah, artinya bahasa dan pikiran yang terjadi pada perkembangan karakter pada saat penyampaian pesan yang mengandung nilai positif yang akan mempengaruhi karakter pada anak untuk menghidari psikologis anak terhadap pesan yang disampaikan orang tuanya.

Komunikasi memang menjadi peranan penting bagi orang tua terhadap anak - anaknya dalam membentuk karakter. Komunikasi selalu senantisa dilakukan oleh orang tua baik itu komunikasi verbal maupun non verbal dapat membuat karakter anak menjadi lebih percaya diri, berilaku mandiri, keterbukaan diterapkan memberikan nasehat yang dapat meningkatan kepribadian karaktek anak menjadi lebih baik, meskipun terkadang kekerasan atau hukuman tidak dapat dihindarkan. Tetapi, hal ini tidak membuat orang tua mudah terkecoh untuk ringan tangan dengan memperlakukan anak dengan kasar.

\section{Referensi}

Agus Irianto, Hasdi Aimon Herman Nirwana, \& Agung Tri Prasetia. (2018). Komunikasi Interpesonal antara Orang Tua dan Anak Remaja serta Identitas Diri Remaja. Studi di Bina keluarga Remaja Parupuk Tabing, Koto tengah, Padang, Sumsssatera Barat. Populasi 26 (1), 16-25..

Handyani Meni. (2016). Peran komunikasi antarpribadi dalam keluarga untuk menumbuhkan karakter anak usia dini. Jurnal Ilmiah Visi Pptl Paudni 11 (1), , 1-2.

Indrawan Y, Aprianti A. (2019). Komunikasi orang tua dan anak tiri terhadap anak dalam membangun kepercayaan. e-Proceeding of Management : 6 (2), 2-3.

Indriani desy. (2018). Komunikasi Interpersonal Antara Orang tua dengan Anak. (Study di Kelurahan Adi Jaya Kecamatan Terbanggi Besar Lampung Tengah), 37-38.

Indriani Fitria, L. A., (2020). Komunikasi interpesonal antara orang tua dan anak dalam pembentukan karakter. (Studi Tentang Duplikasi Karakter Anak di Desa Sesela Kecamatan Gunungsari Kabupaten Lombok Barat), 10-11.

Jatmikowati, E.A. (2018). Efektifitas Komunikasi Orang Tua terhdap Kepribadian Interpesonal Anak. PEDAGOGI: Jurnal Anak Usia Dini dan Pendidikan Anak Usia Dini 4 (2), 7-8.

Kholifah, Umi, Muladi, dan Yoto. (2019). Analisis Kemampuan Berfikir Kreatif dan Komunikasi pada Penerapan Blended Project bas ed Matakuliah Komunikasi Data dan jaringan Komputer. Jurnal pendidikan: Teori, Penelitian dan Pengembangan, 4(3), 338 - 345.

Lestari, Sri. (2018). Psikologi Keluarga: Penanaman Nilai dan Penanganan Konflik dalam Keluarga. Jakarta: Prenadanedia Group

Lubis, R. R., Irwanto, I., \& Harahap, M. Y. (2019). Increasing Learning Outcomes and Ability Critical Thinking of Students Through Application Problem Based Learning Strategies. International Journal for Educational and Vocational Studies, 1(6),, 524-527.

Mohibu, A. (2015);. Peran Komunikasi Orang Tua dalam Minat Belajar Anak. Acta Diurna 4 (4) .

Mulyana, Deddy. (2018). Ilmu Komunikasi Suatu Pengantar. Bandung: PT Remaja Rosdakarya

Rakhmawati. (2015). Peran keluarga dalam Pengasuh Anak. Konseling Realigi: Jurnal Bimbingan Konseling Islam, 6 (1), 1-18.

Ramadhani Rio. (2013). Komunikasi Interpersonal Orang tua dan anak dalam membentuk Perilaku Positif Anak pada Murid Sdit Cordova Samarinda. eJournal ilmu Komunikas, 
Solicha, F. N., Safitri, D., \& Kurniawan, N. (2020). Peran orang tua dalam menentukan pilihan Kuliah anak. Edukasi IPS, 4(2), 8-17.

Sugiyono. (2018). Metode penelitian kuantitatif dan kualiatif. Bandung: Albeta, Cv. 